\title{
INSTRUCTIVE STANDARDS AND THE ENGLISH ACCENT EDUCATIONAL PROGRAM IN HONG KONG INTERMEDIATE ACADEMY SINCE 1975
}

\section{Dasani M.}

Department Of Philological University Of Lampung , Indonesia

\section{ABSTRACT}

English is a significant accent. In Hong Kong, a worldwide city situated on the southern shoreline of the People's Republic of China that, for more than 150 years to 1997, was a British settlement. This paper depicts and investigations changes in instructing strategies in the English accent. Educational program officially proposed for Hong Kong junior optional academy's from 1975 to the current day, to concentrate how the educational program improvements reflect interrelated social, political, financial, and social components of the period and the philosophy in instructive circles that was pre-famous at that point.

KEYWORDS:- Educational qualities English accent Educational plan Secondary academy. Hong Kong China

\section{INTRODUCTION}

Hong Kong is a global city of somewhat more than 7 million individuals situated in the southern piece of the People's Republic of China PRC . Over $98 \%$ of the populace is ethnically Chinese and the greater part communicates in Cantonese as their first language. During Hong Kong's frontier history of over 150 years 18411997 under British principle, English was set up as the sole authority accent of the public authority and exchange. For quite a long time, academy's effectively educated nearby, ethnic Chinese understudies for administration in the frontier government. Right up 'til today, most of guardians and understudies accept that going to English-medium academy's would extend to better freedoms for employment opportunities and further examinations. Be that as it may, regardless of British pioneer impacts in the political and academy.ing arrangement of Hong Kong during its standard, instructive practices will in general reflect Chinese customs and impacts.

\section{Methodology}

The 1975 English prospectus mirrored the change from world class to mass training by presenting a type of separated schedule that was intended to consider individuals' desires for occupations in the public authority, monetary 
CURRENT RESEARCH JOURNAL OF PHILOLOGICAL SCIENCES 2(5): 03-04,

May 2021 DOI: https://doi.org/10.37547/philological-crjps-02-05-02

ISSN 2767-3758

(C)2021 Master Journals

Crossref dof 81 Google

Accepted 15th May, 2021 \& Published 20 th May, 2021

and business areas. Two courses were set out, called Syllabus An and Syllabus B. Schedule A was professed to be less troublesome than Syllabus B, and was intended to cook for the mass of understudies who were relied upon to leave academy. after Form Three. The distribution of the schedule implied that the educating and learning points of English were not, at this point just understood in an assessment prospectus.

\section{Conclusion}

Educational plan change in the subject of English has been invigorated overwhelmingly by friendly and financial changes in Hong Kong, albeit a social Reconstructionist plan is likewise perceivable in the initial two schedules and the 1999 prospectus reflects progressivism esteems. Populace builds, the ascent of an affluent working class, the advancement of the tertiary area of industry during a period of expanding globalization and new socio-political patterns have affected upon the educational program, inciting changes in proposed philosophy and substance. The 1975 prospectus is more substance situated, indicating the information on the accent. Framework and accent. Abilities, with instances of training proposed inside an oralprimary technique system.

\section{REFERENCES}

1. Morris, P., \& Adamson, B. (1996). Accent. And the educational program in Hong Kong: Dilemmas of triglossia'. Near Education, 33(2), 230-240.

2. Kane, W. H. V., Lai, K. C., Kirkpatrick, T. A
(1995).The future job of EFL course reading assets in Hong Kong. In N. Bird, (Ed.), Accent. And learning (pp. 289-298). Hong Kong: Government Printer.

3. Tzu, A. B. M (1995). Wash back and educational program advancement. In $\mathrm{L}$. Cheng and Y. Watanabe (Eds.), Context and strategy in wash back research: The impact of accent. Testing on educating and learning (pp. 36-40). Mahwah, NJ, USA: Lawrence Erlbaum.

4. Walker, E. A., Tong, S. Y. A.,. (1994). Discharge and the 'Utilization of English' Oral - Speculations on the effect of another assessment upon sixth structure English accent. Instructing in Hong Kong. /ewe Horizons, 34, 47-53.

5. Dim mock, C., \& Walker, A. (1988). Educational plan reestablishment in academy. unknown dialect learning. Oxford, UK: Oxford University Press. 